\title{
Costs of delivery approaches for providing livelihood projects to local communities as part of REDD+ programmes: An analysis from Madagascar
}

\author{
JAMES L. MACKINNON*1, LUCIANO ANDRIAMARO ${ }^{2}$, ANDONIAINA RAMBELOSON², \\ MIALY RAZAFINDRAZAKASOA ${ }^{2}$ AND CELIA A. HARVEY \\ ${ }^{1}$ Haughead, Rickarton, Stonehaven, AB393TH, UK, ${ }^{2}$ Conservation International Madagascar, Lot II W 27 D - Ankorahotra - P.O. Box $5178-$ \\ Antananarivo-101, Madagascar and ${ }^{3}$ Moore Center for Science, Conservation International, 2011 Crystal Drive Suite 500, Arlington, VA 22202, \\ $U S A$
}

Date submitted: 4 November 2016; Date accepted: 29 October 2017; First published online 19 December 2017

\section{SUMMARY}

Providing benefits to local people from forest conservation programmes is an important issue for policy makers. Livelihood projects are a common way to provide benefits, but there is little information about their costs. We analysed 463 livelihood projects in the Ankeniheny-Zahamena Corridor Reducing Emissions from Deforestation and Degradation (REDD+) pilot project in Madagascar to understand how different approaches to delivering livelihood projects affect costs. We compared costs across four approaches: conservation agreements, small grants, direct implementation and application of social safeguards. The approach impacted overall costs and the proportion of funds reaching communities. Projects implemented as safeguards were most expensive and had the lowest proportion of expenditures reaching the community. Projects provided as part of conservation agreements directed the highest proportion of expenditures to communities. Our results highlight that how livelihood projects are delivered has implications for project costs and community benefits and should be an important consideration in the design and implementation of REDD+ and forest conservation policies.

Keymords: benefit sharing, community costs, livelihood projects, project costs, REDD+, social safeguards, transaction costs

\section{INTRODUCTION}

A central issue for policy makers of forest conservation programmes and of national programmes for Reducing Emissions from Deforestation and Degradation (REDD+) is how to ensure these programmes provide benefits to local

\footnotetext{
*Correspondence: Dr James MacKinnon email: jameslachlanmackinnon@gmail.com

Supplementary material can be found online at https://doi.org/10.1017/S0376892917000571
}

people (REDD+ Safeguards Working Group 2013; Holmes $\&$ Potvin 2014). One option is to include livelihood projects for local communities as part of forest conservation programmes. Numerous landscape-scale initiatives to reduce deforestation have already been piloted (Chenost et al. 2013; WeatherleySingh \& Gupta 2015). These REDD+ pilots typically include small-scale livelihood projects (e.g. support for agricultural production, fish farming and beekeeping) both as means of reducing local pressure on forests and also as means of improving local livelihoods (Cerbu et al. 2009; Lawlor et al. 2013). Despite widespread use of livelihood projects in REDD+ pilots, there is surprisingly little information available about the best way of delivering projects, what their costs are and how much local communities gain, not only in the context of REDD+, but also for forest conservation programmes more broadly (e.g. Pham et al. 2009; Rendón Thompson et al. 2013; Roe et al. 2015; Wright et al. 2015). Such information is critical for estimations of the costs of national REDD+ programmes (e.g. Brimont 2014) and for policy makers who aim to design and implement REDD+ and forest conservation policies.

To understand the costs of implementing livelihood projects, we compiled detailed cost data from a REDD+ pilot in the Ankeniheny-Zahamena Corridor (CAZ) in eastern Madagascar (Fig. S1, available online). The CAZ REDD+ pilot includes 370000 ha of rainforest. REDD+ preparation activities started in 2005 (Conservation International 2013) and have been supported by various donors. The CAZ has been certified under the Verified Carbon Standard (Rainforest Alliance 2013). Provision of community benefits is a central objective of the REDD+ pilot and hundreds of small-scale livelihood projects ('microprojects') have been implemented to improve local livelihoods and support forest conservation (Ministère de l'Environnement et des Forêts 2012; Conservation International 2013). In addition, microprojects have also been provided to compensate vulnerable households for restrictions of access to forest resources following the World Bank's safeguard policy (World Bank 2013).

The specific goals of our research were to characterize the overall costs of delivering microprojects and to examine how different approaches of project delivery affected both the

This is an Open Access article, distributed under the terms of the Creative Commons Attribution licence (http://creativecommons.org/licenses/by/4.0/), which permits unrestricted re-use, distribution, and reproduction in any medium, provided the original work is properly cited. 
overall cost and the proportion of available funds spent in the community and per household. We compared detailed cost data from 463 livelihood microprojects that were delivered by Conservation International (CI) using four different approaches at CAZ from 2006 to 2014.

We focused on measuring transaction costs to understand how much money gets spent at the community level. Environmental policies such as REDD+ should be designed to minimize transaction costs because high transaction costs erode the gains that a policy can provide (Coggan et al. 2010). Here, we define transaction costs as the costs of services, travel and salaries incurred by the organizations delivering the microproject. By contrast, we consider the costs of local labour, materials and agricultural inputs to be the money spent on a microproject at the community level. Although the need to minimize the transaction costs of conservation and livelihood projects is recognized as an important issue in the literature (e.g. Naidoo et al. 2006; Rendón Thompson et al. 2013; Kurashima et al. 2014; Pham et al. 2014) and is a key concern of policy makers, published information comparing the costs of different livelihood projects is limited.

Our study provides detailed information on the relative transaction costs of different delivery approaches and highlights which ones provide the greatest proportion of funding to communities. The available data on benefits provided by the livelihood projects did not allow us to compare the effectiveness of different delivery approaches in this study. While a study of the cost effectiveness of different delivery approaches would be optimal, the scarcity of data about costs of livelihood projects delivered in the context of REDD+ makes our study valuable for national policy makers who are currently designing national REDD+ strategies and benefitsharing mechanisms and urgently need information on how different project delivery mechanisms affect costs. It will also be useful for practitioners interested in the practicalities of delivering livelihood microprojects within forest conservation projects (e.g. Corbera \& Schroeder 2011).

\section{METHODS}

We conducted our study in the landscape surrounding the CAZ REDD+ pilot, which is a mosaic of agricultural land, forest patches, tree plantations and grassland inhabited by subsistence farmers who cultivate rice and other crops in smallholdings (typically $<1 \mathrm{ha}$ ). Many of these farmers also use forest products from the CAZ REDD+ pilot. Most farmers live below the national poverty line and lack access to basic services (health, schools, electricity, running water, etc.). In addition, many experience seasonal food insecurity (Harvey et al. 2014).

We defined 'microprojects' as distinct activities provided to a group of local residents (a community group) at one locality that aimed to increase food security, increase revenues or provide social infrastructure or services. The community groups were community-based organizations within a village whose members had a common interest such as farmer associations, women's groups and community forest management groups. Each microproject was distinct in that it was planned for a particular group of people and the activities were supported over a discrete period of time (though project duration varied). We use the term 'microproject' to avoid confusion with projects that international donor organizations funding similar work typically refer to as 'small'. For example, the Global Environment Facility Small Grant Program is for small projects up to US\$50 000, whereas microprojects at CAZ had a mean cost of US\$2746. Typical microprojects included support for agroforestry, beekeeping, cultivation of staple food crops, cash crop (e.g. ginger or coffee) production, livestock rearing, fish farming, building or repairing smallscale agricultural infrastructure and education (Table 1).

The microprojects were provided to community groups using four different delivery approaches: conservation agreements, direct implementation, small grants and application of social safeguards (Table 2). Under the conservation agreements ('Agreements'), CI and communities agreed on community conservation activities, including community patrols and monitoring for key species and threats, in return for a mixture of direct payments and livelihoodsupporting microprojects (Niesten et al. 2010). Under the direct implementation ('Direct'), microprojects were provided to local community groups directly by CI staff, sometimes with the help of a company or individual with specialist rural development experience (a contractor). Under the small grants approach ('Grant'), CI provided funds to local nongovernmental organizations (NGOs) to manage a small grants programme. The NGOs publicized the grants programme through village meetings. Community groups then applied for microprojects and the NGOs delivered the microprojects. In the application of the social safeguards approach ('Safeguard'), microprojects were used as part of a social safeguards process (Ministère de l'Environnement et des Forêts 2012) following Operational Procedures 4.12 of the World Bank (World Bank 2013) to compensate households identified as suffering access restrictions due to protection of the CAZ forests. A social safeguards assessment identified 2500 households likely to lose access to forest resources and microprojects were provided as compensation. To allow comparison of the safeguards with the other approaches where the beneficiaries were community groups, the costs for households within the same Fokontany (Madagascar's smallest administrative unit, typically including two to three villages in the study area) were grouped such that the 'community group' was composed of all the households that had received safeguard microprojects within a single Fokontany. The safeguard microprojects were provided by contractors.

While most of the microprojects did address issues that have been identified as conservation threats (Table 1), this was not a condition of providing the microprojects. The principal objective of each microproject was to provide livelihood benefits to local residents. However, the microprojects were implemented as part of the broader REDD+ project that includes specific conservation interventions such as the 
Table 1 Types, mean duration and number of participants in microprojects implemented in the Ankeniheny-Zahamena Corridor from 2006 to 2014 .

\begin{tabular}{|c|c|c|c|c|}
\hline Microproject type & Description of project activities & $\begin{array}{l}\text { Number of } \\
\text { projects }\end{array}$ & $\begin{array}{l}\text { Mean and range of } \\
\text { duration (months) }\end{array}$ & $\begin{array}{l}\text { Mean and range of } \\
\text { number of participants }\end{array}$ \\
\hline Agroforestry & $\begin{array}{l}\text { Training and provision of fruit and plants } \\
\text { for mixed tree/crop forest gardens }\end{array}$ & 38 & $15(1-21)$ & $22(9-81)$ \\
\hline Beekeeping & $\begin{array}{l}\text { Apiculture training and provision of } \\
\text { equipment and bees }\end{array}$ & 44 & $7(2-9)$ & $61(3-276)$ \\
\hline Cash crops & $\begin{array}{l}\text { Training and provision of materials/plant } \\
\text { stock for ginger and coffee cultivation }\end{array}$ & 12 & $8(5-13)$ & $28(20-35)$ \\
\hline Support to education & $\begin{array}{l}\text { Construction or repairs to schools, } \\
\text { support to teachers' salaries }\end{array}$ & 12 & $6(5-9)$ & $113(90-135)$ \\
\hline Fish farming & $\begin{array}{l}\text { Training, provision of fish and } \\
\text { construction of small-scale fish ponds }\end{array}$ & 26 & $9(5-21)$ & $47(22-99)$ \\
\hline $\begin{array}{l}\text { Small-scale farm } \\
\text { infrastructure }\end{array}$ & $\begin{array}{l}\text { Construction or repairs to small-scale } \\
\text { irrigation systems }\end{array}$ & 29 & $8(5-11)$ & $20(20-20)$ \\
\hline $\begin{array}{l}\text { Livestock production } \\
\text { (including poultry) }\end{array}$ & $\begin{array}{l}\text { Training and provision of } \\
\text { materials/animals for rearing chickens, } \\
\text { ducks and pigs }\end{array}$ & 107 & $8(2-13)$ & $64(8-476)$ \\
\hline $\begin{array}{l}\text { Precautionary food } \\
\text { storage }\end{array}$ & $\begin{array}{l}\text { Establishment of rice granaries and food } \\
\text { banks to reduce the impact of lean } \\
\text { periods when there is no rice production }\end{array}$ & 24 & $9(6-15)$ & $71(19-160)$ \\
\hline $\begin{array}{l}\text { Cultivation of staple food } \\
\text { crops }\end{array}$ & $\begin{array}{l}\text { Training and provision of materials/seed } \\
\text { for production of rice, beans, corn, } \\
\text { potatoes and cassava }\end{array}$ & 171 & $10(3-21)$ & $129(1-1511)$ \\
\hline
\end{tabular}

creation and enforcement of a protected area, improved sustainable management of forests and conservation awareness raising. With the exception of safeguards microprojects, the community groups agreed on microprojects through consensual decision making with local CI staff, local NGOs or the contractors responsible for delivery of the microproject (Table 3). The microprojects were chosen on the basis of the priorities of the local community groups, but also taking into account the available budget, technical feasibility and capacity of local NGOs or contractors to deliver the microprojects. In the case of safeguard microprojects, the types of microprojects provided were predetermined based on a safeguards assessment (Ministère de l'Environnement et des Forêts 2012) that was intended to identify suitable mitigation or compensation measures for negative impacts caused by the REDD+ project.

\section{Data collection}

We identified 463 microprojects from CI's database of grants and contracts awarded and extracted data from technical reports, financial reports and CI's accounts. In some cases, we requested additional data from partner organizations when there were gaps in reports. Technical information included location, name of recipient community group, microproject type, microproject activities and the number of recipient households. Financial data included total project costs, costs at the community level, costs of any intermediaries (e.g. contractors or partner NGOs for the grants programme) and costs of oversight and monitoring by CI. We were unable to quantify the costs associated with the initial project design and fundraising, hence our analysis focuses on the actual delivery of the microprojects. Monitoring costs for the microprojects have also been excluded from the analysis because they varied considerably depending on the requirements of different donors. Including monitoring costs would therefore have created bias that reflected differences in donor requirements rather than any fundamental difference among the microproject delivery approaches. Costs such as time or any material provided by the beneficiary community groups were also not consistently quantified and so have not been included.

For the analysis, we grouped cost data into four broad categories: management costs (salaries, management fees/overheads and equipment); travel and meeting costs; input costs (building materials and agricultural inputs); and contractor costs (details in Table S1).

To understand where the costs were incurred, we identified and classified each expense at the level of the lead organization (CI), the intermediary organization (NGO or contractor) and the community group that received the microproject. For example, costs of CI staff overseeing a microproject programme were considered 'lead costs', costs for training done by a partner NGO were considered 'intermediary costs' and costs of materials provided to the community were classified as 'community costs'. We use the term 'transaction costs' in our analysis to refer to the costs incurred by the lead and intermediary organizations. 
Table 2 Summary of the key differences between the four approaches for delivering microprojects in the Ankeniheny-Zahamena Corridor (Madagascar). $\mathrm{CAZ}=$ Ankeniheny-Zahamena Corridor; $\mathrm{CBO}=$ Community-based organization; $\mathrm{CI}=\mathrm{Conservation} \mathrm{International}$; $\mathrm{NGO}=$ Non-governmental organization; REDD $+=$ Reducing Emissions from Deforestation and Degradation.

\begin{tabular}{|c|c|c|c|c|}
\hline \multirow[t]{2}{*}{ Issue } & \multicolumn{4}{|c|}{ Approach } \\
\hline & Small grants & Conservation agreements & Direct projects & Safeguards \\
\hline $\begin{array}{l}\text { How the recipient } \\
\text { community group } \\
\text { was chosen }\end{array}$ & Requested by CBOs & $\begin{array}{l}\text { Community Forest } \\
\text { Management Group (a } \\
\text { CBO composed of forest } \\
\text { users) in areas chosen by } \\
\text { CI as priorities }\end{array}$ & Requested by CBOs & $\begin{array}{l}\text { Households } \\
\text { identified during } \\
\text { a safeguards } \\
\text { assessment by an } \\
\text { independent } \\
\text { assessor }\end{array}$ \\
\hline Target group & $\begin{array}{l}\text { CBOs in villages next to } \\
\text { the CAZ protected } \\
\text { area/REDD+ pilot } \\
\text { project }\end{array}$ & $\begin{array}{l}\text { Forest users in CBOs } \\
\text { responsible for forest } \\
\text { management }\end{array}$ & $\begin{array}{l}\text { CBOs in villages next to the } \\
\text { CAZ protected } \\
\text { area/REDD+ pilot } \\
\text { project }\end{array}$ & $\begin{array}{l}\text { Households } \\
\text { identified as } \\
\text { being negatively } \\
\text { affected by the } \\
\text { protected } \\
\text { area/REDD+ } \\
\text { pilot project }\end{array}$ \\
\hline $\begin{array}{l}\text { How the microproject } \\
\text { was chosen }\end{array}$ & $\begin{array}{l}\text { By the CBO (in } \\
\text { discussion with the } \\
\text { NGO responsible for } \\
\text { delivery to determine } \\
\text { feasibility) }\end{array}$ & $\begin{array}{l}\text { By the CBO (in discussion } \\
\text { with CI to determine } \\
\text { feasibility) }\end{array}$ & $\begin{array}{l}\text { By the CBO (in discussion } \\
\text { with CI to determine } \\
\text { feasibility) }\end{array}$ & $\begin{array}{l}\text { By a third-party } \\
\text { assessor }\end{array}$ \\
\hline $\begin{array}{l}\text { Who delivered the } \\
\text { microproject to the } \\
\text { community group }\end{array}$ & A local NGO & CI staff or a contractor & CI staff or a contractor & Contractor \\
\hline Source of funding & Various, raised by CI & Various, raised by CI & $\begin{array}{l}\text { Government of } \\
\text { Madagascar/World Bank }\end{array}$ & $\begin{array}{c}\text { Government of } \\
\text { Madagascar/ } \\
\text { World Bank }\end{array}$ \\
\hline $\begin{array}{l}\text { Focus on groups or } \\
\text { individuals }\end{array}$ & Groups (a CBO) & Groups (a CBO) & Groups (a CBO) & $\begin{array}{l}\text { Individual } \\
\text { households (but } \\
\text { costs were } \\
\text { grouped for } \\
\text { analysis) }\end{array}$ \\
\hline $\begin{array}{l}\text { Contractual } \\
\text { arrangements } \\
\text { between } \\
\text { community group } \\
\text { and organization } \\
\text { responsible for } \\
\text { project delivery }\end{array}$ & $\begin{array}{l}\text { Written contract or a } \\
\text { verbal agreement } \\
\text { recorded in meeting } \\
\text { minutes }\end{array}$ & Written contract & $\begin{array}{l}\text { Verbal agreement recorded } \\
\text { in meeting minutes }\end{array}$ & Written contract \\
\hline $\begin{array}{l}\text { Specific conservation } \\
\text { activity associated } \\
\text { with the } \\
\text { microproject? }\end{array}$ & No & Yes, explicit in the contract & No & No \\
\hline $\begin{array}{l}\text { Conditionality on } \\
\text { conservation } \\
\text { activities? }\end{array}$ & No & Yes & No & No \\
\hline $\begin{array}{l}\text { Continuity of } \\
\text { microprojects }\end{array}$ & $\begin{array}{l}\text { Provided just once, but } \\
\text { CBO could apply again } \\
\text { for subsequent grants }\end{array}$ & $\begin{array}{l}\text { Approximately annual and } \\
\text { renewed based on } \\
\text { availability of funding } \\
\text { and completion of agreed } \\
\text { conservation activities }\end{array}$ & Provided just once & Provided just once \\
\hline
\end{tabular}


Table 3 Summary of the mean total costs (US\$ \pm SE) of each microproject approach and type. Table S4 shows the same information for transaction costs only.

\begin{tabular}{|c|c|c|c|c|c|}
\hline \multirow{2}{*}{$\begin{array}{l}\text { Microproject } \\
\text { type }\end{array}$} & \multicolumn{4}{|c|}{ Approach } & \multirow[t]{2}{*}{ Total } \\
\hline & Conservation agreement & Direct & Small grants & Safeguards & \\
\hline Agroforestry & & & $1346 \pm 74(n=38)$ & & $1346 \pm 74(n=38)$ \\
\hline Beekeeping & $1126 \pm 175(n=4)$ & & $612 \pm 1(n=19)$ & $4420 \pm 593(n=21)$ & $2476 \pm 399(n=44)$ \\
\hline Cash crop & $1124 \pm 424(n=4)$ & & $4532 \pm 278(n=8)$ & & $3396 \pm 533(n=12)$ \\
\hline Education & $810 \pm 65(n=12)$ & & & & $810 \pm 65(n=12)$ \\
\hline Fish farming & $1224(n=1)$ & $726 \pm 3(n=15)$ & $1550 \pm 388(n=10)$ & & $1062 \pm 165(n=26)$ \\
\hline Infrastructure & $1596 \pm 378(n=6)$ & $147 \pm 0(n=11)$ & $1522 \pm 0(n=12)$ & & $1016 \pm 148(n=29)$ \\
\hline Livestock & $1612 \pm 385(n=10)$ & $640 \pm 51(n=46)$ & $2693 \pm 337(n=26)$ & $6991 \pm 1149(n=25)$ & $2713 \pm 370(n=107)$ \\
\hline $\begin{array}{l}\text { Precautionary } \\
\text { food storage }\end{array}$ & $1679 \pm 217(n=24)$ & & & & $1679 \pm 217(n=24)$ \\
\hline $\begin{array}{l}\text { Staple food } \\
\text { crops }\end{array}$ & $1904 \pm 182(n=35)$ & $768 \pm 155(n=25)$ & $2328 \pm 184(n=70)$ & $10346 \pm 2195(n=41)$ & $3936 \pm 597(n=171)$ \\
\hline Total & $1589 \pm 104(n=96)$ & $630 \pm 50(n=97)$ & $1999 \pm 108(n=183)$ & $7951 \pm 1118(n=87)$ & $2746 \pm 246(n=463)$ \\
\hline
\end{tabular}

All cost information was recorded at the level of individual microprojects. Costs for CI and any intermediaries were therefore sometimes split across several projects since such costs usually covered multiple projects. For example, from 2010, CI employed a full-time member of staff to manage the small grants programme. To allocate his salary to individual microprojects, we divided the annual cost by the number of microprojects that were awarded for that particular year under the grants programme. Similarly, intermediary costs such as for trainings often covered several community groups at the same time. In such cases, the training cost was split equally between the microprojects of the community groups.

Costs were recorded in Malagasy Ariary and adjusted to 2014 costs using the Consumer Price Index (http://knoema. com/atlas/Madagascar/CPI-inflation). These inflationadjusted costs were converted to US dollars using the exchange rate on 31 December 2014 published by Oanda.com (2561.04 Ariary to US\$1).

\section{Statistical analyses}

We used linear mixed models (LMMs) to test for differences in various measures of cost between the four delivery approaches. LMMs are appropriate because the data are hierarchical (observation data from the different delivery approaches can include multiple project types) and the sample size varies across approaches (Zuur et al. 2012). We therefore controlled for variability in costs associated with microproject type by including microproject type as a random effect. To account for the effect of accessibility of microproject location on costs, we included estimates of the Euclidean distance of microprojects to the closest tarred road and to the closest major town as covariates in the model. Further information on how distances were estimated and on the form of the LMMs is included in the Supplementary Material. Measures of cost used as response variables in each of the separate LMMs were the total microproject costs, the amount spent on a microproject in the community, the proportion of total costs that was spent in the community, the cost per household (total cost divided by the number of recipient households) and the value received per household (amount spent at the community level divided by the number of recipient households). We included the measure of value received per household as we expect this figure to reflect the value of a project as perceived by a recipient household since it only includes the costs of the project at the community level.

We also used LMMs with the same form described above to test for differences between the four approaches in the proportion of expenditure in different cost categories (management, travel and meetings, inputs and contractors). Cost variables were log transformed, while proportion data were transformed using the arcsine of square roots. For each of the analyses, we used the Akaike information criterion and Bayesian information criterion to choose the most parsimonious LMM. The two criteria were calculated under assumptions of homogenous variances, heterogeneous variances for approach, heterogeneous variances for type and heterogeneous variances for both type and approach. The results for model selection are provided in Tables S2 and S3. We used Fisher's least significant difference tests to compare for differences across approaches. All analyses were carried out using InfoStat (Di Rienzo et al. 2016) and algorithms from the lme4 library of R (R Core Team 2015).

\section{RESULTS}

Total microproject costs averaged $\$ 2746 \pm 246$ (SE; Table 3). The transaction costs (i.e. the combined costs of lead and intermediary organizations) averaged $41 \% \pm 1 \%$ (SE) of the total project costs.

There were significant differences between the approaches for all of the cost variables that we analysed (Table 4). The project approaches varied in their overall project costs, with safeguards having higher costs than the other approaches 
Table 4 Estimated means and SEs of cost variables (US\$) based on the best model for each variable. Data on the number of recipient households were unavailable for the conservation agreements. All the cost variables (US\$) presented are $\log _{10}$ transformed except the proportion data, which are transformed using arcsine of the square roots. In each case, the letters $\mathrm{a}, \mathrm{b}$ and $\mathrm{c}$ are used to indicate significant differences between the means based on Fisher's least significant difference tests. Means with the same letters are not statistically different. Table $\mathrm{S} 4$ presents the same data but as descriptive statistics rather than transformed model outputs.

\begin{tabular}{|c|c|c|c|c|c|c|}
\hline Variable & Safeguards & Small grants & Conservation agreements & Direct implementation & $F$ & $p$ \\
\hline Total project cost & $3.69 \pm 0.13 \mathrm{a}$ & $3.18 \pm 0.08 b$ & $3.11 \pm 0.08 \mathrm{~b}$ & $2.62 \pm 0.11 \mathrm{c}$ & 14.39 & $<0.0001$ \\
\hline $\begin{array}{l}\text { Total spend at community } \\
\text { level }\end{array}$ & $3.24 \pm 0.19 \mathrm{a}$ & $2.89 \pm 0.12 \mathrm{a}$ & $3.00 \pm 0.11 \mathrm{a}$ & $2.38 \pm 0.15 b$ & 5.2 & 0.0092 \\
\hline Cost per household & $2.77 \pm 0.11 \mathrm{a}$ & $1.61 \pm 0.07 \mathrm{~b}$ & - & $1.38 \pm 0.12 \mathrm{~b}$ & 23.97 & $<0.0001$ \\
\hline Value per household & $2.35 \pm 0.11 \mathrm{a}$ & $1.35 \pm 0.07 b$ & - & $1.26 \pm 0.13 b$ & 11.45 & $<0.0001$ \\
\hline $\begin{array}{l}\text { Proportion spent at } \\
\text { community level }\end{array}$ & $0.69 \pm 0.09 \mathrm{c}$ & $0.82 \pm 0.06 \mathrm{bc}$ & $1.06 \pm 0.05 \mathrm{a}$ & $0.96 \pm 0.07 \mathrm{ab}$ & 5.98 & 0.0052 \\
\hline \multicolumn{7}{|c|}{ Proportion of total costs composed of: } \\
\hline Management costs & $0.89 \pm 0.10 \mathrm{a}$ & $0.72 \pm 0.07 \mathrm{ab}$ & $0.55 \pm 0.07 \mathrm{~b}$ & $0.56 \pm 0.09 \mathrm{~b}$ & 3.2 & 0.0481 \\
\hline Travel costs & $0.22 \pm 0.05 \mathrm{ab}$ & $0.31 \pm 0.03 \mathrm{a}$ & $0.09 \pm 0.03 \mathrm{c}$ & $0.18 \pm 0.04 \mathrm{bc}$ & 8.21 & 0.0012 \\
\hline Input costs & $0.25 \pm 0.11 \mathrm{c}$ & $0.73 \pm 0.07 b$ & $0.98 \pm 0.08 \mathrm{a}$ & $0.80 \pm 0.09 \mathrm{ab}$ & 9.94 & 0.0004 \\
\hline Contractor costs & $0.54 \pm 0.05 \mathrm{a}$ & $0.09 \pm 0.03 \mathrm{c}$ & $0.05 \pm 0.03 \mathrm{c}$ & $0.37 \pm 0.04 b$ & 41.03 & $<0.0001$ \\
\hline
\end{tabular}

and agreements and grants costing more than direct microprojects.

The total amount spent per microproject at the community level was significantly lower for direct microprojects in comparison to the other approaches. However, the overall proportion of microproject costs spent at the community level was lowest in safeguards, highest for agreements and intermediate for the grants and direct microprojects.

The cost per household was greater in safeguards than either small grants or direct implementation. The differences between cost per household for microprojects provided directly and through grants were not significant. Similarly, the value per household (i.e. the cost of the support that households actually receive) was greater in safeguard microprojects than in either small grants or direct implementation. Data on the number of households benefitting from agreements were not available for comparison.

There were also differences across microproject approaches in the types of costs incurred (Table 4). Safeguards had higher management costs than agreements and direct microprojects. The management costs of grants were intermediate. Travel costs were highest for grants and lowest in the agreements. Input costs were highest for agreements and lowest for safeguards. Finally, contractor costs were greater in safeguards than in any of the other approaches and lowest for agreements and grants.

\section{DISCUSSION}

Our results indicate that the way in which livelihood projects are delivered within REDD+ pilots can have significant impacts on project costs as well as on how much money reaches local communities. Therefore, this deserves careful consideration in the design and implementation of REDD+ and forest conservation policies. At CAZ, we found significant differences in microproject costs across different approaches, with microprojects delivered as part of a safeguards process costing significantly more than other approaches and direct projects costing the least. The proportion of funding that reached a community also varied significantly across approaches, with agreements and direct microprojects spending the greatest proportion at the community level, while safeguards spent the least. High management costs and the costs of contractors account for the lower proportion of funding reaching communities in the case of safeguards. While we have found no comparable studies that have contrasted the costs of delivering microprojects through different approaches, we suspect that our results would hold for similar analyses of the costs of safeguards. This is because safeguards frequently need specialist and relatively expensive contractors (World Bank 2004) and the microprojects need to be delivered to specific (usually very remote) households identified as part of a social safeguards assessment.

Our results have important policy implications for the design of livelihood projects in REDD+ programmes. First, it is clear that the transaction costs of delivering livelihood projects in REDD+ programmes can be high and need to be carefully factored into project design and funding. In our study, an average of $41 \%$ of project costs were transaction costs incurred at the intermediary or lead organization, while the remaining 59\% was spent at the community level (though the proportions varied greatly across projects). We have not found any studies looking explicitly at the transaction costs of delivering livelihood projects and therefore it is difficult to determine whether these costs should be considered high or low in comparison to other regions where livelihood projects have been implemented. Brimont (2014) modelled costs for Madagascar's national REDD+ programme under two different scenarios: one based on community payments for ecosystem services and another based on using multiple 
protected areas to reduce deforestation. She found that these scenarios would result in local communities benefitting from $66 \%$ and $44 \%$ of total costs, respectively (i.e. transaction costs of $34 \%$ and $56 \%$ using our definition). In a review of the transaction costs of enacting environmental policies, Coggan et al. (2010) reported transaction costs ranging from $8 \%$ to $102 \%$ depending on how transaction costs are calculated and expressed. In our study, it is likely that we are overestimating transaction costs due to the way we are defining them, as some of the costs at the lead and intermediary organizations could be argued to be directly related to producing the livelihood microproject. However, high transaction costs may be an inevitable component of livelihood projects conducted in remote rural areas, often characteristic of REDD+ activities, given the high costs of transporting inputs, organizing activities and providing technical and financial oversight in remote locations with poor transportation and communications infrastructure and limited institutional capacity. High transaction costs may reduce the ability of REDD+ projects to provide meaningful benefits to local communities.

REDD+ policy makers and implementers need to estimate transaction costs in order to ensure that projects are successfully delivered and monitored. In Madagascar, for example, the government has proposed to allocate a fixed proportion (as high as $50 \%$ ) of carbon credit revenue to community microprojects (CIRAD 2013), but it is not clear if this proportion includes transaction costs. REDD+ policy makers in Madagascar and elsewhere will need to clarify how these transaction costs will be covered and by whom. Reducing transaction costs, such as by providing fewer larger projects that benefit many households rather than providing many smaller projects (e.g. Wunder 2009; Pham et al. 2014), also merits greater attention. However, providing livelihood projects at scale will involve trade-offs such as giving recipients less choice about the types of projects they can receive.

A second implication of our results is that REDD+ policy makers and implementers should carefully consider what approach is most appropriate for delivering livelihood projects in a given region. Project costs are often an important determinant of project design (Naidoo et al. 2006; Armsworth 2014) and if the priority is to reduce project delivery costs, then implementers should use approaches that minimize the use of intermediaries or specialist consultants. If the intent is to maximize the proportion of funds going to local communities (as often highlighted by REDD+ policy makers), then our study suggests that direct implementation or conservation agreements are likely good options. However, cost considerations are only one of many factors affecting the choice of approach. Ultimately, the priority should be reducing the cost while maximizing impact. In our study, we have only considered the costs of microprojects and not their overall effectiveness in delivering livelihood benefits or conservation outcomes in both the short and long term due to the lack of available data on project benefits.
Publications on the effectiveness of conservation activities in achieving conservation and socioeconomic impacts are becoming more common (e.g. Brimont 2014; Rasolofoson et al. 2015; Desbureaux et al. 2016; Rasolofoson et al. 2017), but we are not aware of any that compare the cost effectiveness of different approaches to providing livelihood projects. A rigorous analysis of types and magnitudes of the benefits provided by different microproject approaches would allow comparison of the cost effectiveness and would help fill the important knowledge gap on both the conservation and social impacts of livelihood projects (Roe et al. 2015; Wright et al. 2015; Baylis et al. 2016).

Other factors that will affect project design include logistical factors, such as the number of projects that need to be delivered, the timescale of project implementation, the remoteness of target communities and the ability of local organizations to provide technical and administrative support to projects (e.g. Naidoo et al. 2006; Blom et al. 2010). In many sites (including the CAZ), building the long-term capacity of local organizations to deliver livelihood projects and lead conservation activities (e.g. by involving them as intermediaries in project delivery or having them manage small-scale grants) may be a prerequisite for ensuring longterm impact, despite potentially increasing initial overall project costs. For example, capacity building of local NGOs was an objective of the small grants programme at the CAZ, but our results show that the relatively high management costs and travel costs of this programme meant that less funding got to the community in comparison to the conservation agreement approach.

A third take-home message for policy makers is that there is a need to think carefully about how to most cost-effectively implement livelihood microprojects delivered within the context of safeguards processes. The delivery of social safeguards differs from other approaches because microprojects are targeted towards a very specific group of people who have been identified through a safeguards assessment process as being negatively affected by the REDD+ project (World Bank 2013). The microprojects are specifically designed to compensate for the losses incurred due to restricted access to forest resources. In addition, safeguards should be provided at the beginning of a REDD+ project to help communities immediately seek alternative opportunities (World Bank 2013). This creates pressure to provide many projects in a short timeframe. For this reason, social safeguard projects are commonly delivered by specialist contractors who are capable of delivering complex rural development projects quickly. Inevitably, the use of such contractors increases project costs and a lower proportion of funding is spent in local communities. However, in our study, individual households actually received the greatest funding under this approach, indicating that the value of these projects to participants is greater than that of other approaches (assuming that each approach provides similar benefits). REDD + managers and policy makers need to be aware of the high costs of safeguard projects and explore ways of simplifying safeguard 
procedures or finding alternative ways to compensate communities. In addition, the difficulties of accurately identifying which households merit compensation by safeguard procedures (e.g. Poudyal et al. 2016) suggest it may be necessary to identify alternative ways of both effectively identifying and compensating remote communities affected by REDD+.

Finally, there is an urgent need for much more rigorous assessment of both the costs and benefits of livelihood projects implemented within REDD+ interventions and forest conservation efforts more generally (Naidoo et al. 2006; Miller 2014; Evans et al. 2015) to inform policy decisions and field implementation. The lack of data on the costs of livelihood projects probably reflects both the difficulty (and cost) of tracking these data and a reluctance of organizations to share these data due to the possibility of exposing negative or unintended outcomes (McKinnon et al. 2015). In our study, it was only possible to compile the necessary financial information due to unusually detailed records kept by CI's Madagascar programme that classified every expense by type of expense and by activity. Even so, compiling these data required the equivalent of two full-time staff for one year. There is an urgent need for project implementers to design financial accounting systems, monitoring systems and reporting standards that track the costs and benefits of livelihood projects so that this information can be used to improve decision-making processes and promote costeffective and equitable implementation of REDD+. This paper provides an important first step in understanding the costs of livelihood projects delivered in the context of REDD+ and highlights the importance of how projects are implemented in affecting these costs.

\section{ACKNOWLEDGEMENTS}

We thank Lovaharisoa Rakotomamonjy, Narindra Ralefomanana and Alivony Ravelomanantsoa for help collating cost information, CI Madagascar (particularly Hantanirina Ravololonanahary, Soloson Ramanahadray and Tokihenintsoa Andrianjohaninarivo) for locating key documents, Andriambolantsoa Rasolohery for Figure S1 and Fabiano Godoy, Jenny Hewson, Julia Jones, Steve Panfil, Agustin Silvani, Karyn Tabor and two anonymous reviewers for helpful comments on the manuscript. We are very grateful to Sergio Vilchez for supporting the statistical analysis.

\section{FINANCIAL SUPPORT}

This research was funded as part of the P4GES project, 'Can Paying for Global Ecosystem Services Reduce Poverty' (Grants NE-K010220-1 and NE-K010115-1), supported by the Ecosystem Services and Poverty Alleviation (ESPA) programme of the United Kingdom. The ESPA programme is funded by the Department for International Development (DFID), the Economic and Social Research Council (ESRC) and the Natural Environment Research Council (NERC).

\section{CONFLICT OF INTEREST}

All of the authors have worked at or currently work at Conservation International, which is currently the designated manager of the Ankeniheny-Zahamena protected area and REDD+ project. Conservation International was involved in the fundraising for and implementation of all of the livelihood microprojects from which data have been collected in this study.

\section{Supplementary material}

To view supplementary material for this article, please visit https://doi.org/10.1017/S0376892917000571

\section{References}

Armsworth, P.R. (2014) Inclusion of costs in conservation planning depends on limited datasets and hopeful assumptions. Annals of the New York Academy of Sciences 1322: 61-76.

Baylis, K., Honey-Rosés, J., Börner, J., Corbera, E., Ezzine-de-Blas, D., Ferraro, P.J., Lapeyre, R., Persson, U.M., Pfaff, A. \& Wunder, S. (2016) Mainstreaming impact evaluation in nature conservation. Conservation Letters 9: 58-64.

Blom, B., Sunderland, T. \& Murdiyarso, D. (2010) Getting REDD to work locally: Lessons learned from integrated conservation and development projects. Environmental Science E Policy 13: 164174.

Brimont, L. (2014) Le coût de la Reduction des Emissions issues de la Déforestation et la Dégradation des Forêts (REDD+) à Madagascar. PhD thesis. Paris, France: Paris Institute of Technology.

Cerbu, G., Minang, P.A., Swallow, B. \& Meadu, V. (2009) Global survey of REDD projects: What implications for global climate objectives? ASB Policy Brief No. 12. ASB Partnership for the Tropical Forest Margins, Nairobi [www document]. URL http://www.worldagroforestry.org/downloads/Publications/ PDFS/BR09159.pdf

Chenost, C., Gardette, Y.-M., Demenois, J., Grondard, N., Perrier, M. \& Wemaere, M. (2013) Bringing Forest Carbon Projects to the Market. Paris, France: Office National des Forêts.

CIRAD (2013) Assessment of the design elements of a sharing mechanism of benefits from carbon revenues: 'Madagascar CAZ' REDD Project. Report prepared for the World Bank's BioCarbon Fund [www document]. URL https://wbcarbonfinance.org/docs/biocf-CAZ-Benefit-sharingstudy-April-2014-EN.pdf

Coggan, A., Whitten, S.M. \& Bennett, J. (2010) Influences of transaction costs in environmental policy. Ecological Economics 69: 1777-1784.

Conservation International (2013) Carbon Emission Reduction Project in the Corridor Ankeniheny-Zahamena (CAZ) Protected Area, Madagascar. Project Description for Verified Carbon Standard Validation [www document]. URL http://www.vcsprojectdatabase.org/\#/project_details/1311

Corbera, E. \& Schroeder, H. (2011) Governing and implementing REDD+. Environmental Science ES Policy 14: 89-99.

Desbureaux, S., Aubert, S., Brimont, L., Karsenty, A., Lohanivo, A.C., Rakotondrabe, M., Razafindraibe, A.H. \& Razafiarijaona, J. (2016) The impact of protected areas on 
deforestation: an exploration of the economic and political channels for Madagascar's rainforests (2001-2012). HAL Id: halshs01278872 [www document]. URL https://halshs.archivesouvertes.fr/halshs-01278872

Di Rienzo, J.A., Casanoves, F., Balzarini, M.G., Gonzalez, L., Tablada, M. \& Robledo, CW. (2016) InfoStat. Córdoba, Argentina: Universidad Nacional de Córdoba.

Evans, M.C., Tulloch, A.I., Law, E.A., Raiter, K.G., Possingham, H.P. \& Wilson, K.A. (2015) Clear consideration of costs, condition and conservation benefits yields better planning outcomes. Biological Conservation 191: 716-727.

Harvey, C.A., Rakotobe, Z.L., Rao, N.S., Dave, R., Razafimahatratra, H., Rabarijohn, R.H., Rajaofara, H. \& MacKinnon, J. (2014) Extreme vulnerability of smallholder farmers to agricultural risks and climate change in Madagascar. Philosophical Transactions of the Royal Society B 369: 20130089.

Holmes, I. \& Potvin, C. (2014) Avoid re-inventing the wheel in a people-centered approach to REDD+. Conservation Biology 28: 1380-1393.

Kurashima, T., Matsuura, T., Miyamoto, A., Sano, M., Tith, B. \& Chann, S. (2014) Changes in income structure in frontier villages and implications for REDD+ benefit sharing. Forests 5: 28652881.

Lawlor, K., Madeira, E.M., Blockhus, J. \& Ganz, D.J. (2013) Community participation and benefits in REDD+: A review of initial outcomes and lessons. Forests 4: 296-318.

McKinnon, M.C., Mascia, M.B., Yang, W., Turner, W.R. \& Bonham, C. (2015) Impact evaluation to communicate and improve conservation non-governmental organization performance: The case of Conservation International. Philosophical Transactions of the Royal Society B 370: 20140282.

Miller, D.C. (2014) Exploring global patterns of international aid for linked biodiversity conservation and development. World Development 59: 341-359.

Ministère de l'Environnement et des Forêts (2012) Plan de Gestion Environnementale et de Sauvegarde Sociale de la Réserve de Ressources Naturelles Ankeniheny-Zahamena. MINENVEF [www document]. URL http://documents.banquemondiale.org/ curated/fr/2012/03/19798438/madagascar-third-environmentprogram-support-project-environmental-assessment-vol-10-10plan-de-gestion-environnementale-de-sauvegarde-sociale-de-lareserve-de-ressources-naturelles-ankeniheny-zahamena

Naidoo, R., Balmford, A., Ferraro, P.J., Polasky, S., Ricketts, T.H. \& Rouget, M. (2006) Integrating economic costs into conservation planning. Trends in Ecology and Evolution 21: 681-687.

Niesten, E., Zurita, P. \& Banks, S. (2010) Conservation agreements as a tool to generate direct incentives for biodiversity conservation. Biodiversity 11: 5-8.

Pham, T.T., Campbell, B.M. \& Garnett, S. (2009) Lessons for propoor payments for environmental services: An analysis of projects in Vietnam. Asia Pacific Fournal of Public Administration 31: 117133.

Pham, T.T., Moeliono, M., Brockhaus, M., Ngoc Le, D., Wong, G.Y. \& Manh Le, T. (2014) Local preferences and strategies for effective, efficient, and equitable distribution of PES revenues in Vietnam: Lessons for REDD+. Human Ecology 42: 885-899.

Poudyal, M., Ramamonjisoa, B.S., Hockley, N.J., Rakotonarivo, S.O., Gibbons, J.M., Mandimbiniaina, R., Rasoamanana, A. \& Jones, J. P. (2016) Can REDD+ social safeguards reach the 'right' people? Lessons from Madagascar. Global Environmental Change 37: $31-42$.
R Core Team (2015) R: A language and environment for statistical computing. R Foundation for Statistical Computing, Vienna, Austria [www document]. URL http://www.R-project.org

Rainforest Alliance (2013) Verified Carbon Standard Validation Assessment Report for 'Carbon Emissions Reduction in the Corridor Ankeniheny-Zahamena (CAZ) Protected Area, Madagascar' [www document]. URL http://www.vcsprojectdatabase.org/ \#/project_details/1311

Rasolofoson, R.A., Ferraro, P.J., Jenkins, C.N. \& Jones, J.P.G. (2015) Effectiveness of community forest management at reducing deforestation in Madagascar. Biological Conservation 184: 271277.

Rasolofoson, R.A., Ferraro, P.J., Ruta, G., Rasamoelina, M.S., Randriankolona, P.L., Larsen, H.O. \& Jones, J.P.G. (2017) Impacts of community forest management on human economic well-being across Madagascar. Conservation Letters 10: 346-353.

REDD+ Safeguards Working Group (2013) Non-Carbon Benefits in REDD+: Providing Incentives and Addressing Methodological Issues. Briefing paper for 38th session of SBSTA, Bonn, 3-14 June 2013 [www document]. URL http://www.greenpeace.org/ international/Global/international/briefings/forests/2013/ NCBs.pdf

Rendón Thompson, O.R., Paavola, J., Healey, J.R., Jones, J.P.G., Baker, T.R. \& Torres, J. (2013) Reducing Emissions from Deforestation and Forest Degradation (REDD+): Transaction costs of six Peruvian projects. Ecology and Society 18: 17.

Roe, D., Booker, F., Day, M., Zhou, W., Allebone-Webb, S., Hill, N.A.O, Kumpel, N., Petrokofsky, G., Redford, K.H., Russell, D., Shepherd, G., Wright, J. \& Sunderland, T.C.H. (2015) Are alternative livelihood projects effective at reducing local threats to specified elements of biodiversity and/or improving or maintaining the conservation status of those elements? Environmental Evidence 4: 22.

Weatherley-Singh, J. \& Gupta, A. (2015) Drivers of deforestation and REDD+ benefit-sharing: A meta-analysis of the (missing) link. Environmental Science ES Policy 54: 97-105.

World Bank (2004) Involuntary Resettlement Sourcebook. Planning and Implementation in Development Projects. The World Bank, Washington DC [www document]. URL http://documents. worldbank.org/curated/en/2004/01/ 5159399/involuntary-resettlement-sourcebook-planningimplementation-development-projects-vol-1-2

World Bank (2013) Operational Procedures 4.12. Involuntary Resettlement. World Bank Procedures Manual [www document]. URL http://web.worldbank.org/WBSITE/EXTERNAL/ PROJECTS/EXTPOLICIES/EXTOPMANUAL/0, contentMDK:20064610 menuPK:64701637 pagePK: 64709096 piPK:64709108 theSitePK:502184 isCURL:Y, 00.html

Wunder, S. (2009) Can payments for environmental services reduce deforestation and forest degradation? In: Realising REDD: National Strategy and Policy Options, eds. A. Angelsen, with M. Brockhaus, M. Kanninen, E. Sills, W.D. Sunderlin \& S. Wertz-Kanounnikoff, pp. 213-224. Bogor, Sudan: CIFOR.

Wright, J.H., Hill, N.A., Roe, D., Rowcliffe, J.M., Kümpel, N.F., Day, M., Booker, F. \& Milner-Gulland, E.J. (2015) Reframing the concept of alternative livelihoods. Conservation Biology 30: 713.

Zuur, A.F., Saveliev, A.A. \& Ieno, E.N. (2012) Zero Inflated Models and Generalized Linear Mixed Models with R. Newburgh, UK: Highland Statistics Limited. 